\title{
PRAXEOLOGICAL AND ETHICAL LIMITS FOR INCORPORATION OF ETHICS AND CSR INTO A CORPORATE STRATEGY AND OPERATIONAL ACTIVITIES
}

\begin{abstract}
Summary
One can observe in the whole Europe a general trend to include ethics and corporate social responsibility into corporate strategy and operational activities. Institutional, public, corporate and competitors' pressure reinforce the increasing popularity of the corporate social responsibility concept. It sometimes even happens that it is done without any preoccupation with risks and threats it may have to the business bottom line and to the interests of those stakeholders the company should first attend. We describe the praxeological limits, submitted to the criteria of efficiency and effectiveness, of including ethics and corporate social responsibility into a corporate strategy and operational activities by reviewing the literature on these issues. We also discuss the other side of the problem, namely its ethical limits, in general terms though, focusing on axiological aspects of these matters. The analysis concludes by emphasizing the practical sense of the golden mean.
\end{abstract}

Key words: corporate strategy \& operational activities, corporate social responsibility, ethics, golden mean, praxeology.

\section{Introduction}

The aim of this paper is to analyze the limits of the incorporation of ethics and $\mathrm{CSR}^{2}$ in organizational strategy and in operational activities. The limits are analyzed from the point of view of efficiency and effectiveness, which constitute praxeological criteria, as well as from the viewpoint of ethical criterion.

Firstly, we present an overview on the issue of corporate social responsibility which dominated the political, economic and business discourse in Europe in the last decade. In the second chapter, we also present the problem of subsequent analysis and its context. In the third chapter of the article, we stress that excessive reliance on ethics and CSR, as a measures to solve problems, may not be the best solution, causing, sometimes, counterproductive results for business and society. In the next chapter, we present and discuss some examples of threats of incorporation of ethics and CSR in strategy and operational activities of the company, which seem to appear more frequently in

1 Olgierd Swiatkiewicz, Ph.D., professor of Escola Superior de Tecnologia de Setúbal, Instituto Politécnico de Setúbal, Portugal, e-mail: olgierd.swiatkiewicz@estsetubal.ips.pt. Marek Michalski, Ph.D., professor of Universidad Rey Juan Carlos, Madryt, e-mail: marek.michalski@urjc.es.

${ }^{2}$ CSR - corporate social responsibility. 
the literature and speeches of experts. In the fifth chapter, we raise the question of means and ends, as well as the issue of instrumentalization of ethics and the need to apply in all cases the Aristotelian principle of golden mean. We conclude the article by suggesting that ethicists should pay more attention to the problems of efficiency and effectiveness and that businesspersons and business researchers should be more concerned with problems of the ethical dimension of business and CSR.

\section{An overview on Corporate Social Responsibility}

Business ethicists, social and business scholars and business practitioners have devoted considerable time to studying the business-society relationship [Carroll 1979, 1991, 1993; Drucker 1984; Freeman 1984; Wood 1991; Clarkson 1995; Porter, Kramer 2006] trying to conceptualize ethical behavior in terms of business practices of corporations in society. Much of this work has focused on theorizing what kinds of responsibilities corporations have towards society and what the consequences of respective actions or inactions are. Some scholars have argued that corporations have no responsibility beyond legally making profits for its shareholders [Friedman 1970], others that corporations have extensive responsibilities towards stakeholders and that these responsibilities derive from ethical principles and moral values [Carroll 1993, 1999; Freeman 1984].

In general, literature distinguishes among several types of CSR, most of which presume that corporations are social institutions that are tightly integrated into the society, meaning that they are socially, economically and politically interconnected with many other social institutions and groups of people whose well-being they affect directly or indirectly.

A concept that reflects the former and helps define more clearly the social responsibilities of companies is Edward R. Freeman's [Freeman 1984] stakeholder theory. It is both a paradigm for understanding the business-society relationship and a business management strategy which stresses the importance of CSR. It assumes that a corporation is composed of stakeholders or "persons or groups that have, or claim ownership, rights or interests in a corporation and its activities, past, present and future" [Clarkson 1995 p. 106]. These stakeholders, for example, may include customers, employees, shareholders, suppliers, local communities and the public in general.

Other scholars like Polyani [Polyani 1952], Davis [Davis 1960, 2001], Cannon [Cannon 1994], Ulrich and Sarasin [Ulrich, Sarasin 1995], Weiser and Zadek [Weiser, Zadek 2000], have contributed to the discussion on CSR. However, useful and interesting, most if not all of the key concepts discussed by these authors reveal that CSR is still very much a Western-oriented concept based on a Western set of values. The majority of the scholars contributing to the CSR debate come from Western countries ${ }^{3}$ and their perceptions of CSR are built on theories and practices that originated in Western corporations. That is also why most of the international standards on codes of conduct for

\footnotetext{
${ }^{3}$ Mainly Europe and America.
} 
corporations lack a comprehensive global context. Somehow, what is still missing in the discussions and debates - accounting for a gap in the business ethics field - is a perspective of CSR that is inclusive of a diverse range of cultural, social and religious backgrounds, other than that of the West.

Irrespective of a specific reality of a given country, its overall economic position, or situation in each sector of the economy, where we can still find many cases of socially irresponsible companies [Smith-Hillman 2007], the notion of CSR is well received and generally accepted in a definition process of many contemporary corporate strategies. CSR represents a declared political will continuously supported by an increased interest of state institutions, institutions of the EU and its member states, [European Commission 2001, 2009; Bé 2005; Diamantopoulou 2005; Eberhard-Harribey 2006; Souto 2009] as well as other international and non-governmental organizations (NGOs), mass media and also businesses themselves [Souto 2009].

Liedekerke and Dubbink [Liedekerke, Dubbink 2008] emphasize that studies on CSR considered as the flagship issues in business ethics have paradoxically been developed more in Europe than in the USA. Lewicka-Strzałecka at the very beginning of her article states that the notion of CSR has "become increasingly popular in Poland, both in academic circles through researching its theoretical foundations, and among managers and businessmen who want to put these theories to use in everyday business practice" [Lewicka-Strzałecka 2006 p. 440].

The management of many companies share the opinion presented in a large part of business ethics literature e.g. Jose and Thibodeaux 1999; Hosmer 2000; Husted, Allen 2000; Porębski 2000; European Commission 2001; Bird, Hall, Momentè, Reggiani 2007; Heugens, Dentchev 2007; Fiłek 2007], those ethics and CSR may bring profits. Other authors, like: [Lewicka-Strzałecka 1999, 2003; Husted, Allen 2000; Koslowski 2002; Enderle 2004; Valentine, Godkin, Cyrson, Fleischman 2006; Sharp, Zaidman 2010] indicate also a positive link between economic performance of a company and its social responsibility. Some like: [Moreira, Cunha 1997; Hosmer 2000; Husted, Allen 2000; McWilliams, Siegel 2001; Burchell, Cook 2006; Whitehouse 2006; Valentine et al. 2006; Heugens, Dentchev 2007; Souto 2009] go even further and analyze essential prerequisites for obtaining a competitive advantage by companies considering ethics and CSR as their strategy. Husted and Allen [Husted, Allen 2000], Bé [Bé 2005], Whitehouse [Whitehouse 2006] and the European Commission [European Commission 2009] include ethics and CSR among corporate goals, or simply write about a company's social strategy.

This growing will or belief in a positive impact of ethics and CSR on a company's performance compels us, however, to give some thought and find answers to a very relevant question. What are the praxeological limits for application of ethics and CSR in the process of corporate strategy definition? It seems that such ventures should have certain limits or constraints hindering generation of undesirable and quite often unintended results in the process of a company's strategy definition. Such effects are in most cases related to modification of organizational behaviors denoting the change in the scope of responsibility - from limited to complete and unlimited.

Many arguments, which have been used in an attempt to answer this question, can be found in the classic article by Milton Friedman [Friedman 1970]. It seems, however, 
that his isolated opinion failed to convince the majority and it gave rise to a never-ending wave of criticism. In our opinion it might be worthwhile, taking advantage of the decline in an initial euphoric mood about CSR - at least with regard to Europe [Liedekerke, Dubbink 2008], taking up an analysis of benefits and losses brought about as an attempt to answer this question.

The integration of ethics and CSR into company's strategy may be useful for the organization and indicate a prudent attitude of its managers. It is understood that it is to the advantage of the organization itself as well as its managers [Friedman 1970; Whawell 1998; Kaler 2000; Burchell, Cook 2006; Whitehouse 2006; Pater, Lierop 2006; Souto 2009; Sharp, Zaidman 2010], to prevent the exposal of business to potential losses, or real threats, like pressures from $\mathrm{NGOs}^{4}$, costs of litigation, deterioration of company's image or reputation and loss of customer's trust, as a result of accusations of monopolistic practices, sexual harassment, discrimination, corruption, cronyism, influence peddling, nepotism, insider trading etc. Thus a doubt arises that maybe it would be less risky, from the viewpoint of efficiency and effectiveness in attaining company's goals, not to take ethics and CSR into consideration.

According to McWilliams and Siegel there is a certain level of investment in CSR which yields maximum profit and meets at the same time stakeholder's expectations with regard to such venture. Such a level may be defined with the use of cost/benefit analysis. Managers, entrepreneurs and companies' executives should treat CSR related decisions exactly the same way as all other investment decisions [McWilliams and Siegel 2001]. This view is shared also by Fiłek, who writes that: actions taken under CSR may be treated as investment [Fiłek 2007 p. 21]. However, Sharp and Zaidman argue that CSR differs significantly from 'standard' business strategy initiatives [Sharp, Zaidman 2010 p. 53].

Similarly, to many publications from an already vast field of business ethics we tend to consider ethics and CSR as synonymous concepts [Vogel 1991; Ferrell, Fraedrich 1997; Husted, Allen 2000; Enderle 2004; Rego, Cunha, Costa, Gonçalves 2006], without going into deliberations on their differentiation. Following Liedekerke and Dubbink [Liedekerke, Dubbink 2008], we believe that a complex notion of CSR overlaps such different concepts as business ethics, corporate responsibility, corporate/organizational citizenship, environmental stewardship, corporate philanthropy etc., makes a clear-cut determination of limits as well as differentiation between the several notions impossible. It may seem that the absence of a clear definition of the concept hidden under the term CSR, because of this very fact, has become its essential advantage and value. Dunne states, that "without any formal determination or widely accepted definition, CSR has come to mean so very much" [Dunne 2007 p. 373].

Praxeology as a general methodology, or as a theory of efficient human action [Dudley 1995; Gasparski 1995, 1996; Freeman, Phillips 1996; Swiatkiewicz 1997], plays in this analysis only an auxiliary and instrumental role. Praxeology makes possible an assessment of integrating ethics and CSR into the corporate strategy from the viewpoint of dual criterion of efficiency-effectiveness of an undertaken action. Although praxeology and ethics belonged to the spectrum of mutual scientific interests of practical phi-

${ }^{4} \mathrm{NGOs}$ - non-governmental organizations. 
losophy of Tadeusz Kotarbiński who developed the Polish school of praxeology, Kotarbiński himself recognized a separate analysis of these two notions as belonging to different theoretical orders. At the same time, he emphasized their interrelations and practical consequences in real action [Lewicka-Strzałecka 2003].

The above brief analysis may lead to a conclusion that ethics and CSR have been transformed into some sort of panacea for failure of strategies declared by businesses. In the following part of our article, we shall try to clarify this issue.

\section{Can ethics and CSR constitute panacea for all evil?}

According to Paine within this harmonious picture of etbics and economics as allies can be found traces of wishful thinking and seeds of complacency [Paine 2000 p. 319]. There are also many myths about economic (managerial) activity on all levels of behavioral analysis i.e. general, organizational and individual [Geva 2001]. It is possible, or even probable that in the long run ethics will in general pay off; however, in specific cases of individual undertakings it shall not be profitable [Kaler 2000].

Similar or even identical opinions are often presented in the business ethics literature [Moreira, Cunha 1997; Fiłek 2007; Souto 2009]. Periods of economic boom, growth and development are more conducive to the integration of ethics and CSR into corporate activities than times of crisis, or economic downturn, forced savings and coupled with the above prevailing feeling of insecurity and uncertainty [Carr 2003; Vuontisjärvi 2006; Souto 2009]. Even then, "it is not evident how companies should respond to their stakeholders and identify their social responsibilities [Pater, Lierop 2006 p. 339]. Heugens and Dentchev [Heugens, Dentchev 2007] suggest that the CSR related risk might seriously affect the company's possibilities to achieve its goals. In particular, with regard to the so-called organizational risk, it may seriously disturb basic processes of organizational transformations and thus hinder the attainment of internal goals.

According to Buchholz and Rosenthal [Buchholz, Rosenthal 1998], from the CSR conceptualization does not result any mechanism which would help solving the problem of organizational resources allocation. Linkage and operationalization of three goals [triple bottom line] imposed upon, or voluntarily accepted by an organization: economic, social and environmental, i.e. the so-called people, planet, profit, have continuously been the source of problems [Fisher, Lovell 2003]. Whitehouse [Whitehouse 2006], states in her study that the companies' management (16 international organizations based in the United Kingdom) considers measurement of success in implementation of their own CSR related policy as difficult.

Having in mind the above opinions, we believe that the inclusion of other objectives like social and environmental at the same level as an economic goal may lead to the situation whereby the attainment of an economic goal will fall much short of expectations. The attained level may be so low that it will make the survival of a company impossible. In such a position, a company may not be able to solve its own problems, or those of its stakeholders. 
It is being assumed in the business ethics literature that the promotion of ethics and CSR should also help decrease the scale of social and economic problems, or even eliminate some of them (e.g. unemployment, poverty, environmental pollution, social exclusion, global warming etc.), because (un) ethical and socially (ir) responsible behaviors of players in the marketplace condition the functioning of the whole economic system [Argandoña 1989; Lewicka-Strzałecka 1999; Hosmer 2000; Hosmer, Chen 2001; Sen 2002; Koslowski 2002; Souto 2009]. We think, however, that such course of action may also yield results quite opposite to intentions and even detrimental to the society and economy as a whole. Strategies based on imposed ethical standards may be used without paying much attention to whether they are helpful or rather harmful to the society as a whole or some particular social groups..

Ethics and CSR may also be used to obtain a competitive advantage. Such strategy may be illustrated by an example of imposing the ethical convention/standards of one company [monopolist] upon a whole sector of economy [industry] in which this company is operating. In such a case, ethics and CSR are being transformed into instruments strengthening a monopolist position of a company and to a large extend weakening competitive play in the given market. We have similar situations in the case of other factors impeding a perfect competition, like making use of licenses or copyrights. "Ethics strategies may thus be described as anti-competitive practices, which restrain other firms from competing effectively in the marketplace" [Husted, Allen 2000 p. 26].

Strategies incorporating CSR may also undermine a democratic way of a decision making process. When companies get involved in social problems they start making decisions, which may not be in the best interest of the society as a whole [Husted, Allen 2000].

As the strategies including CSR are to contribute to increase the company's value, the choices of such strategies tend to be conservative. They are focused on rather popular goals and undertakings, which are well thought of, or politically correct, without involvement in controversial, or open to different interpretations issues. It is estimated that $80 \%$ of companies' philanthropy is directed to safe issues' [Peel cited by: Husted, Allen 2000].

\section{Potential threats of incorporating ethics and CSR into companies' strategy}

In this part of our analysis, we discuss some threats of incorporating ethics and social responsibility into a company's strategy, which in our view appear mostly in the literature and are predominantly voiced in experts' statements.

Distraction or weaker focus of managers caused by the CSR's incorporation into the company's strategy constitutes a threat to its success, as on the one hand, managers tend to lose sight of the marketplace strategy and on the other, the risk arises of dividing the existing resources into an ever-increasing number of alternative investment undertakings [Heugens and Dentchev 2007]. Such a situation has also a negative impact on managers' behavior weakening their sense of duty towards companies' owners [Friedman 1970; Lewicka-Strzałecka 1999]. 
The acceptance of the CSR as a dominating strategy may also be a threat to the organization in the form of ineffective (non-productive) distribution of its available means and resources. Investment projects, which do not increase effectiveness as well as goals encouraging stakeholders to free-riding behavior, are symptomatic of such threats.

The CSR, being also an investment into public goods is understood here as the use of company's resources for goals that everybody, including competition, could benefit from. This includes also those who in no way contributed to the generation of the public service offer, but now may have wider or full access to such services. From the viewpoint of company's effectiveness, such a situation cannot be accepted. Especially in the long run as managers on the one hand can use such investments as an argument justifying a lack of progress in the attainment of the established goals, and on the other may yield to the pressure or even resign from obtaining economic goals in favor of political or social goals. CSR related expenditure carries also the costs of lost opportunities i.e. opportunity costs. No Euro or USD spent on CSR can be invested in other activity profitable for the company [Kirchler, Hölzl 2003; Heugens, Dentchev 2007].

In addition, another threat arises from the enlargement of the coalition through incorporation of interests of all and not only the crucial (strategic or the most influential) stakeholders. Such a wide coalition may become dysfunctional [inefficient] and lead to chaos and anarchy [Heugens, Dentchev 2007]. Participation and dialogue, as emphasized by Morsing and Schultz, may also relate to expenses and loss of time and, in fact, lead to counterproductive activities that do not build trust, facilitate collaboration or enhance the value of the corporation [Morsing, Schultz 2006 p. 335]. In spite of these apparently strong arguments, we may come across many proponents of the view that the strategic adoption of the CSR, gives an almost endless opportunity of widening the company's stakeholders coalition. In our view, it is at least questionable.

Effectiveness of the strategy can also be affected by its faulty implementation. One of the factors making a successful CSR implementation impossible is the absence of practical indicators for evaluation of its performance. Many of the CSR goals are of qualitative, nearly ephemeral nature making their quantitative measure difficult or even impossible [Fisher, Lovell 2003; Whitehouse 2006; Heugens, Dentchev 2007]. The adoption of CSR activities increases the risk of bad strategy implementation when pivotal stakeholders are turned off by the difficulties of measuring the successfulness of a CSR-based strategy. (...) A lack of employee support can easily lead to further problems with strategy implementation [Heugens and Dentchev 2007, pp. 156-162].

The credibility of a company diminishes when the very notion of CSR becomes blurred and abused. Some companies due to the type of their business are perceived as naturally illegitimate to use such terminology (tobacco, alcohol, pornographic industry as well as arms industry and petrochemical businesses etc.). If such businesses start assuming the CSR related duties and responsibilities they do not automatically improve their public image, or reputation but on the contrary, their present and not very good position may even get worse. The acceptance of the CSR related obligations by the above-mentioned businesses is perceived as insincere and hypocritical. It also leads to a decline of credibility as such action may be interpreted as an indication that the company did something that now requires compensation [Heugens, Dentchev 2007]. 
However, according to Morsing and Schultz [Morsing, Schultz 2006] the situation in this respect has already considerably changed. The present expectations of stakeholders with regard to the companies' CSR are much more unpredictable and concern many sectors, or even at the same time the economy as a whole. We have in mind here such issues as child labor, genetically modified organisms or sweatshops.

The adoption of the CSR strategy by a company makes various social groups aware of (real, potential and sometimes even imaginary) ties between this company and the social problems spelled out in its strategy. Thus, it results in an increased perception of and belief in its full responsibility for bringing the matter to its final solution [Heugens, Dentchev 2007]. Businesses should not usurp or appropriate tasks and problems, which are within the responsibility or under the management of such institutions as central and local governments, NGOs, or civil society. Businesses should not assume chief responsibility for the resolution of all, or even some issues, which are within the duties/responsibilities of others. Companies cannot try to "save the world", but should take upon themselves such tasks which they can responsibly implement [Heugens, Dentchev 2007].

According to the survey carried out by Burchell and Cook [Burchell, Cook 2006], the majority of NGOs and companies' representatives agree that the dialogue about CSR issues between NGOs and companies results in an increase of stakeholders expectations. Such a situation may thus lead to the escalation of demands concerning CSR and requirements from companies. A similar view is expressed by Lewicka-Strzałecka who writes that: One of the unintentional results of the CSR policy can be growing expectations from specific stakeholders, as well as indifference of the local and central government, which is only too glad to dispose of a part of its duties [Strzałecka 2006 p. 444].

Organizations can face a long-term loss of their reputation if they ignore, or do not take into account threats connected with insufficient or erroneous information about the risk related to the assumption of CSR obligations. Inadequate communication with stakeholders, such as lack of transparency and lack of information about reasons why a company assumes the CSR related obligations, as well as the risk involved and the possibility of conflict between groups of stakeholders, may give raise within society and consumer groups to feelings of anxiety and growing concern, which have been until then of potential or hidden nature [Heugens, Dentchev 2007]. Errors in communication with stakeholders with regard to company's obligations undertaken under CSR may result in the perception of such obligations as a part of an ordinary public relations campaign. In turn, the linkage of company's name to specific social or environmental issues may also generate a series of unintended and often negative side effects, independently of the diligence applied in the communication process.

The CSR strategy supporting unpopular or controversial issues ${ }^{5}$ may be unwelcome and meet with disapproval from some social groups, or parts of the society [Husted, Allen 2000].

${ }^{5}$ Like fighting against HIV and helping the AIDS patients at the beginning of the 80ies, struggling against slave labor in Europe, children/pedophilia and women/prostitution smuggling, drug trafficking, corruption in sports, etc. 
According to Sharp and Zaidman, CSR activities differ from other business activities because CSR programs typically require not only traditional monetary donations but also the active involvement of employees as volunteers in social projects. As a result, one can assume that employees involved in CSR programs act both as employees in for-profit organization, and simultaneously as volunteers in a non-for-profit organization [Sharp, Zaidman 2010 p. 52]. This can lead, at least theoretically, to identity dissonance among employees and to the conflicts and divisions within the organization [Sharp, Zaidman 2010].

Consumers are still not well aware of the CSR related companies' actions and those who know something in this respect, if they do not decide immediately to make their purchases based on the best price/quality ratio, they have a lot of trouble in making their choices according to the CSR related criteria. It happens so because customers do not have sufficient and adequate information to make the right decision, or because obtaining such information is too troublesome [Whitehouse 2006]. Furthermore, the [un] ethical conduct of the companies seems to have no significant impact on the purchasing decisions of customers [Lewiska-Strzałecka 2006; Farhangmehr, Malheiro 2007].

Entrepreneurs and firms' executives show little experience and lack of motivation to engage in social problems solving and/or in the resolution of environment protection issues [Friedman 1970; Buchholz, Rosenthal 1998; Husted, Allen 2000]. Hence, firms are not capable of solving such social problems like poverty, illiteracy, military conflicts in Africa, the protection of human rights in Tibet or AIDS [Husted, Allen 2000].

Decisions of companies' management on effective allocation of means and resources are hindered by cultural contexts, which pose a potential source of conflict of interests among a large number of different stakeholders [Bird et al. 2007]. Such situations get even more complicated in the context of multiculturalism. Businesses in this type of environment must take into account interests of stakeholders, whose behavior is based on different and often enough conflicting rules or standards. Stakeholders use different methods of behavior assessment, i.e. what in their view is appropriate and/or acceptable, as there is no universal solution of moral problems [Pater, Lierop 2006].

\section{Axiological question of means and ends}

We shall now attempt to study this problem from a different perspective and depart for a while from the efficiency analysis of applying ethics and CSR to the companies' strategy. We consider now an axiological issue of the means and ends as well as instrumental and ultimate values/principles which have been a never ending subject matter of discussions not only in business ethics but also in other fields.

The strategic form of CSR, being an instrumentalization of ethics, is in general rejected by moral philosophers who believe that acceptance of such CSR form augurs the end of ethics [Liedekerke, Dubbink 2008]. Some business ethics scholars like Bowie [Bowie 2001] believe that ethics may in some cases become non-profitable; however, firms and business people should continue doing what is good or the right things. Now, a question arises whether it is possible or just a wishful thinking? 
In the literature on management and related disciplines, we find many descriptions and case analysis on success in business, which are in general ethically neutral or positively evaluated. In business ethics, to take a lesson, there are many cases referring to violations/infringements of ethical and legal standards for the purpose of economic gains, or survival of the organization. In the history of economic activity, there is no mention on the so-called "good but helpless" executives who ruined a viable company. Handbooks are silent on this topic. Probably because there is little about it to say. In the world of limited resources - as Posner [Posner 1977] states - waste should be considered immoral.

On the other hand, utilitarian or praxeological solutions are chosen where criteria of efficiency and effectiveness (amoral and immoral model of management) are preferred to the ethical dimension and thus the criteria related to the latter are eclipsed. It seems thus that Ossowska's opinion, that dogmatic formulation of etbical standard seems to be inadvisable as it obliterates the importance of their appropriate measuring [Ossowska 1985p. 23] is well founded.

Recognition and analysis of stakeholders which lies in the heart of CSR [McWilliams, Siegel 2001; Burchell, Cook 2006] was aimed at realizing and recognizing the existence of different social groups and their interests in the organization [Freeman 2002]. The main insight was that executives must pay some strategic attention to those groups who were important to the success of their corporations. So far...common sense. (...) Stakeholder capitalism is no panacea. It simply allows the possibility that business becomes a fully buman institution" [Freeman 2002 pp. 112116].

Regarding observations of everyday life experience, Friedman emphasizes that in a free society it need not happen that only "bad" people do "evil" things; it is enough that what is good for some may turn to be wrong for others [Friedman 1997]. This dilemma could be regarded as a business ethics classical dilemma. Such dilemmas, however, do not exclusively belong to the sphere of economic or managerial activity but appear in various areas of human social life [MacIntyre 1997].

The dilemma of dual criterion ethics $v$ s. efficiency is well presented and summed up by Koslowski. He writes that: one would want neither to live in a just society where there is notbing to buy nor in an efficient, rich society that employs its resources for morally reprehensible purposes. (...) The form of co-ordination by way of property, maximization of utility and profit, and the market cannot be the content of the social order and individual action, no more so than this form can be abandoned if freedom and efficiency in the economy are to be secured [Koslowski 2002, pp. 44-67].

John Stuart Mill, considering a diversity and complexity of everyday decisions, as it seems, indicates also superiority of choices based on individual's good sense and collective practical wisdom, rejecting at the same time formalization of ethical standards which, when taking into account the specificity of each situation, should have preference over an individual assessment [Almeida 2010].

In Tadeusz Kotarbiński's works on praxeology and ethics "being efficient in a decent goal" was the ideal of life and the essence of the concept of "trustworthy guardian" [Kotarbiński 1987; Lewicka-Strzałecka 2003].

As a last resort, we can always use the well-known Aristotle's golden mean principle according to which "good and evil are not in this area separated by a clear-cut divider 
but they create a continuum, in which a man after a debate with his own conscience must determine the limits" [Ossowska 1985, p. 234].

Unfortunately, it seems there isn't any good sense, or golden mean measure that can be applied a priori, during the formulation of the company's ethical strategy. We may be coming closer to this measure through becoming more and better ethically educated, getting more sensitivity to different moral situations, by continuous reflection on pros and cons, never however attaining our ultimate goal. The lack of a good sense approach may lead to the situation whereby the process of strategic decision-making shall take a form of an oscillation between the extremities.

\section{Conclusions and future research}

As presented above in our short analysis, there is quite a wide array of praxeological and ethical constraints to the application of ethics and CSR as a constituent element of corporate strategy. This is a fact to be clearly understood both by entrepreneurs, managers as well as by the social actors who promote the ideas of corporate social responsibility.

The constraints presented above can substantially affect the efficiency and effectiveness of the strategy, the possibility of the company to continue its economic activity in a given sector, the continuity of an organization itself and the question of its very survival. However, it does not necessarily have to happen this way. In our viewpoint, as presented here, we by no means attempt to diminish the importance of CSR and benefits of its application for the company and the society per se. We recognize as relevant the search for different forms of developing partner cooperation (government-business-civil society) aimed at the resolution of problems related to the lacks of welfare state [Albareda, Lozano, Tencati, Midttun, Perrini 2008].

Our analysis widens the scope of Heugens and Dentchev's [Heugens, Dentchev 2007] research who, using direct interviews, gathered opinions of the European experts on CSR and then verified them in the organizational environment. Based on the obtained results, Heugens and Dentchev define seven categories of dangers with a differentiated scale of treat to which companies investing in CSR are exposed. Four of them are more concrete and have greater impact within the organization on inter alia the process of internal coordination and mechanisms of corporate governance while the other three are more of a symbolic nature and relate to groups, or people outside the dominating organizational coalition. They affect the level of inter-organizational relations the company takes part in, and to a greater extend influence credibility, reputation and social capital of the organization. The seven types of risks described by Heugens and Dentchev [Heugens, Dentchev 2007] do not of course exhaust the whole spectrum of situations, which restrict possibilities of applying ethics and CSR in companies' strategy. In our paper, we also added five other situations described in literature but it is highly probable that there are many more.

Institutional efforts done by governments, international organizations, NGOs and mass media to promote the idea of CSR, aimed at increasing companies' responsibility 
for the resolution of social and environmental problems, should take into consideration the criteria of ethics and efficiency as well as application of the golden mean principle. Amartya Sen [Sen 2002], remembering the teachings of Buddha, also indicates the "middle path".

Thus, it seems important not only to analyze limits whose exceeding may be related to a decline in efficiency and effectiveness of the strategy, or even, result in its inefficiency and ineffectiveness, but also to study situations in which ethics and CSR may prove to be critical for the success of strategy and maybe even the companies' survival.

We do not endeavor in our analysis to cover the whole issue of such barriers and related to them threats in the application of CSR and ethics in the process of company's strategy definition. Hence, we believe it would be of substantial interest to continue further research on these barriers. Of particular importance seems to be the empirical verification of the cases described here.

Concluding, it seems worthwhile to mention the comment in [Elms, Brammer, Harris, Philips 2010] on relationships between strategic management and business ethics: Whereas research in strategic management may have shifted considerations of ethics too far into background, research in business ethics may have correspondingly placed too much focus on "ethics" and not enough on "business" [Elms, Brammer, Harris, Philips 2010 p. 403].

\section{Bibliography}

Albareda, L., Lozano, J. M., Tencati, A., Midttun, A., \& Perrini, F. 2008 The Changing Role of Governments in Corporate Social Responsibility: Drivers and Responses, "Business Ethics: A European Review", 17 (4), 347-363.

Almeida F. 2010 Valores humanos e responsabilidade social das empresas, Cascais, Portugal, Principia.

Argandoña A. 1989 Las relaciones entre economía y ética, "Research paper" no 166, IESE/ /Universidad de Navarra Barcelona, Spain.

Bé D. 2005 Foreword, [in:] A. Habish, J. Jonker, M. Wegner, R. Schmidpeter (Eds.), Corporate social responsibility across Europe, Springer, Berlin - New York, NY; accessed February 10, 2012, available at http://pt.scribd.com/doc/30804196/ /Corporate-Social-Responsibility, vii-viii.

Bird R., Hall A. D., Momentè F., Reggiani F. 2007 What Corporate Social Responsibility Activities are Valued by the Market?, "Journal of Business Ethics", 76, 189-206.

Bowie N. 2001 The role of Business Ethics: Where Next? Is there a Role for Academics?, "Business Ethics: A European Review", 10 (4), 288-293.

Bremer J. A. 2008 How Global is the Global Compact?, "Business Ethics: A European Review", 17 (3), 227-244.

Burchell J., Cook J. 2006 It is Good to Talk. Examining Attitudes towards Corporate Social Responsibility Dialogue and Engagement Processes, "Business Ethics: A European Review", 15 (2), 154-170.

Cannon T. 1994 Corporate Responsibility - Business Ethics, Governance, Environment, Roles and Responsibilities, Pitman Pub., London, UK. 
Carroll A. B. 1979 A Three-Dimensional Conceptual Model of Corporate Performance, "Academy of Management Review", 4 (4), 497-505.

Carroll A. B. 1991 The Pyramid of Corporate Social Responsibility: Toward the Moral Management of Organizational Stakeholders, "Business Horizons", 34, 39-48.

Carroll A. B. 1993 Business \& Society: Ethics and Stakeholder Management (2nd ed.), SouthWestern Pub., Co Cincinnati, OH:

Carroll A. B. 1999 Corporate Social Responsibility: Evolution of a Definitional Construct, "Business \& Society", 38 (3), 268-295.

Carr P. 2003 Revisiting the Protestant Ethic and the Spirit of Capitalism: Understanding the Relationship between Ethics and Enterprise, "Journal of Business Ethics", 47, 7-16.

Clarkson M. B. 1995 A Stakeholder Framework for Analyzing and Evaluating Corporate Social Performance, "The Academy of Management Review", 20 (1), 92-117.

Davis K. 1960 Can Business Afford to Ignore Social Responsibilities?, "California Management Review", 2, 70-76.

Davis K. 2001 The Social Responsibility of Corporations, "The Corporate Citizen", Corporate Citizenship Unit, Deakin University, 2-8, Melbourne.

Diamantopoulou A. 2005 Foreword, [in:] A. Habish, J. Jonker, M. Wegner, R. Schmidpeter (Eds.), Corporate Social Responsibility across Europe, Springer, Berlin, Germany - New York, NY, accessed February 10, 2012, available at http://pt.scribd.com/doc/ /30804196/Corporate-Social-Responsibility, v-vi.

Dudley P. 1995 Editor's Introduction, [in:] P. Dudley (ed.), Kotarbinski's praxiology, Centre for Systems Studies University of Hull, Hull, UK, xiv-xxix.

Dunne S. 2007 What is Corporate Social Responsibility Now? "Ephemera”, 7 (2), 372-380.

Eberhard-Harribey L. 2006 Corporate Social Responsibility as a New Paradigm in the European Policy: How CSR Comes to Legitimate the European Regulation Process, "Corporate Governance. The International Journal of Business in Society", 6 (4), 358-368.

Elms H., Brammer S., Harris J. D., Phillips R. A. 2010 New Directions in Strategic Management and Business Ethics, "Business Ethics Quarterly", 20 (3), 401- 425.

Enderle G. 2004 Global Competition and Corporate Responsibilities of Small and Medium-Sized Enterprises, "Business Ethics: A European Review”, 13 (1), 51-63.

European Commission 2001 Green Paper, Promoting a European Framework, for Corporate Social Responsibility, 2001, Brussels, accessed May 11, 2011, available at http:/ / eurlex.europa.eu/LexUriServ/LexUriServ.do?uri=COM:2001:0366:FIN:en: PDF.

European Commission, 2009, Towards Greater Corporate Responsibility. Conclusion of EUFunded Research. Brussels, accessed May 11, 2011, available at http://ec.europa.eu/ /research/social-sciences/pdf/policy-review-corporate-social-responsibility_en.pdf.

Farhangmehr M., Malheiro M. A. 2007, As percepções éticas dos consumidores influenciam a sua atitude de compra?, "Revista Portuguesa e Brasileira de Gestão", 5(1), 20-31.

Fiłek J. 2007 Między wolnościa gospodarczq a odpowiedzialnościq społeczna biznesu, [in:] B. Klimczak, A. Lewicka-Strzałecka (eds.), Etyka i ekonomia, PWE, Warsaw.

Fisher C., Lovell A. 2003 Business Ethics and Values, FT Prentice Hall, Harlow, UK Milan, Italy. 
Friedman M. 1970 The Social Responsibility of Business is to Increase its Profits, "The New York Times Magazine", September 13.

Friedman M. 1997 Spolecznq odpowiedzialnościq biznesu jest pomnażnie zysków, [in:] L. V. Ryan CSV, J. Sójka (eds.). Etyka biznesu. Z klasyki współczesnej myśli amerykańskiej, W drodze, Poznań, Poland.

Freeman R. E. 1984 Strategic MAnagement: A Stakeholder Approach, Pitman Pub., Boston, MA.

Freeman R. E., Phillips R. A. 1996 Efficiency, Effectiveness, and Ethics: A Stakeholder View, [in:] W.W. Gasparski, L. V. Ryan CSV (eds.), Human Action in Business: Praxiological and Ethical Dimensions, New Brunswick-London, UK: Transaction Pub..

Freeman R. E. 2002 The Possibility of Stakeholder Capitalism, [in:] L. Zsolnai, W. W. Gasparski (Eds.), Ethics and the Future of Capitalism. New Brunswick - London, UK: Transaction Pub..

Gasparski, W. W. 1995 Wartościowanie driatań, „Prakseologia”, 1-2 (126-127), 15-28.

Gasparski W. W. 1996 Praxiology and Ethics: The Business Ethics Case, [in:] W. W. Gasparski, L. V. Ryan CSV (eds.), Human Action in Business: Praxiological and Ethical Dimensions, Transaction Pub., New Brunswick - London, UK.

Geva A. 2001 Myth and Ethics in Business, "Business Ethics Quarterly", 11 (4), 575-597.

Heugens P., Dentchev N. 2007 Taming Trojan Horses: Identiffing and Mitigating Social Responsibility Risks, "Journal of Business Ethics", 75, 151-170.

Hosmer L. T. 2000 It is Time for Empirical Research in Business Ethics, "Business Ethics Quarterly", 10 (1), 233-242.

Hosmer L. T., Chen F. 2001 Ethics and Economics: Growing Opportunities for Joint Research, "Business Ethics Quarterly", 11 (4), 599-622.

Husted B. W., Allen D. B. 2000 Is it Ethical to Use Ethics as Strategy?, "Journal of Business Ethics", 27, 21-31.

Jose A., Thibodeaux M. S. 1999 Institutionalization of Ethics: The Perspective of Managers, "Journal of Business Ethics", 22, 133-143.

Kaler J. 2000 Reasons to Be Ethical: Self-Interest and Ethical Business, "Journal of Business Ethics", 27, 161-173.

Kirchler E., Hölzl E. 2003 Economic Psychology, [in:] C. L. Cooper, I. T. Robertson (eds.), "International Review of Industrial and Organizational Psychology", 18, 29-89.

Koslowski P. 2002 Ethics of Capitalism, [in:] L. Zsolnai, W.W. Gasparski (eds.), Ethics and the Future of Capitalism, Transaction Pub., New Brunswick-London, UK.

Kotarbiński T. 1987 Pisma etycrne, Ossolineum, Wroclaw, Poland.

Lewicka-Strzałecka A. 1999 Etyczne standarty firm i pracownikow, IFiS PAN, Warsaw, Poland.

Lewicka-Strzałecka A. 2003 Prakseologia a etyka: od filozofii praktycznej Tadeusza Kotarbińskiego do dylematón etyki zycia gospodarczego, „Edukacja Filozoficzna”, 35, 21-36.

Lewicka-Strzałecka A. 2006 Opportunities and Limitations of CSR in the Post-Communist Countries: Polish Case, "Corporate Governance. The International Journal of Business in Society", 6 (4), 440-448.

Liedekerke L., Dubbink W. 2008 Twenty Years of European Business Ethics - Past Developments and Future Concerns, "Journal of Business Ethics", 82, 273-280. 
McIntyre A. 1997 Dlaczego problemy etyki biznesu sq nierozwiazywalne?, [in:] L. V. Ryan CSV, J. Sójka (eds.), Etyka biznesu. Z klasyki wspótczesnej myśli amerykańskiej, W drodze, Poznań, Poland.

McWilliams A., Siegel D. 2001 Corporate Social Responsibility: A Theory of the Firm Perspective, "Academy of Management Review", 26 (1), 117-127.

Moreira P., Cunha M. P. 1997 Ética organizacional: Moda de gestão, escolha moral ou imperativo estratégico?, "Comportamento Organizacional e Gestão”, 3 (2), 347-358.

Morsing M., Schultz M. 2006 Corporate Social Responsibility Communication: Stakeholder Information, Response and Involvement Strategies, "Business Ethics: A European Review", 16 (4), 323-338.

Ossowska M. 1985 Normy moralne. Próba systematyzacji, PWN, Warsaw, Poland.

Paine L. S. 2000 Does Ethics Pay?, "Business Ethics Quarterly”, 10 (1), 319-330.

Pater A., Lierop K. 2006 Sense and Sensitivity: The Roles of Organization and Stakeholders in Managing Corporate Social Responsibility, "Business Ethics: A European Review", 15 (4), 339-351.

Pinto G. R. 2004 Responsabilidade social das empresas: Estado da arte em Portugal, CECOA, Lisboa, Portugal, accessed July 11, 2006, available at www.rso.pt.

Porębski C. 2000 C:y etyka sie opłaca? Zagadniena etyki bižnesu, Antykwa, Kraków - Kluczbork, Poland.

Polyani K. 1957 The Great Transformation: The Political and Economic Origins of our Time, Boston.

Porter M.E., Kremer M.R. 2006 Strategy and Society. The Link between Competitive Advantage and Corporate Social Responsibility, "Harvard Business Review", December 2006, 78-92.

Posner R. A. 1977 Economic Analysis of Law, Little, Brown, Boston, MA.

Rego A., Cunha M. P., Costa N. G., Gonçalves H., Cabral-Cardoso C. 2006 Gestão ética e socialmente responsável, Editora RH, Lisboa, Portugal.

Sen A. 2002 Rozwój i wolność, Zysk i S-ka, Poznan, Poland.

Smith-Hillman A V. 2007 Socially Irresponsible, Unethical or Business as Usual? UK Case of Agros Ltd. and Littlewoods Ltd. v. OFT, "Business Ethics: A European Review", 16 (2), 150-162.

Souto B. F.-F. 2009 Crisis and Corporate Social Responsibility: Threat or Opportunity?, "International Journal of Economic Sciences and Applied Research", 2 (1), 36-50.

Sharp Z., Zaidman N. 2010 Strategization of CSR, "Journal of Business Ethics", 93 (1), $51-71$.

Swiatkiewicz O. 1997 Por que não uma abordagem praxeológica, "Análise Psicológica”, 4 (15), 637-644.

Ulrich P., Sarasin C. 1995 Facing Public Interest. The Ethical Challenges to Business Policy and Corporate Communications, Kluwer Academic Pub., Amsterdam, Holland.

Valentine S., Godkin L., Cyrson E., Fleischman G. 2006 Perceived Ethical V alues and Small Business Problems in Poland, "Business Ethics: A European Review", 15 (1), 76-85.

Vogel D. 1991 The Ethical Roots of Business Ethics, "Business Ethics Quarterly", 1 (2), 101 120. 
Vuontisjärvi T. 2006 The European Context for Corporate Social Responsibility and Human Resource Management: An Analysis of the Largest Finnish Companies, "Business Ethics: A European Review", 16 (3), 271-291.

Weiser J., Zadek S. 2000 Conversations with Disbelievers. Persuading Companies to Address Social Challenges, The Ford Foundation, New York, NY.

Whawell P. 1998 The Ethics of Pressure Groups, "Business Ethics: A European Review", 7 (3), 178-181.

Whitehouse L. 2006 Corporate Social Responsibility: Views from the Frontline, "Journal of Business Ethics", 63 (3), 279-296.

Wood D. 1991 Corporate Social Performance Revisited, "Academy of Management Review", 16 (4), 691-718. 